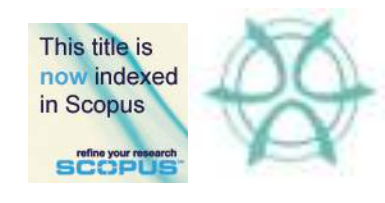

PLANNING MALAYSIA:

Journal of the Malaysian Institute of Planners

SPECIAL ISSUE IV (2016), Page 1 - 16

\title{
MAPPING POVERTY HOT SPOTS IN PENINSULAR MALAYSIA USING SPATIAL AUTOCORRELATION ANALYSIS
}

\author{
M. Rafee Majid ${ }^{1}$, Abdul Razak Jaffar ${ }^{2}$, Noordini Che $\operatorname{Man}^{3}$, Mehdrad Vaziri ${ }^{4}$ \& \\ Mohamed Sulemana ${ }^{5}$ \\ ${ }^{1,2,3}$ UNIVERSITI TEKNOLOGI MALAYSIA \\ ${ }^{4}$ UNIVERSITY OF SOUTH FLORIDA \\ ${ }^{5}$ UNIVERSITY FOR DEVELOPMENT STUDIES, GHANA
}

\begin{abstract}
In September 2000 The Millennium Summit adopted the UN Millennium Declaration, committing nations to a new global partnership to reduce extreme poverty with a deadline of 2015. Eight Millennium Development Goals were formulated of which the eradication of poverty given top priority. However, Malaysia's participation with the UN in dealing with poverty, precede this when it committed itself with the United Nations Decade for the Eradication of Poverty (1997-2006) programme, which was then reinforced when the Millennium Declaration was made in 2000. Nationally, poverty eradication as well as bridging the inequality gap among the major ethnic groups and states has been the main development goal in Malaysia's development agenda since independence. In this regards, the principle of "growth with equity" has been the central theme in all Malaysia's development policies and efforts since independence. Although Malaysia has made significant achievements in reducing the incidence of aggregate poverty across the country from $8.9 \%$ in 1995 down to $1.7 \%$ in 2012 , there still exist pockets of poverty in the rural areas, in certain states/regions and among ethnic groups, as well as in some urban areas. This shows that formulating planning and policy implementation to eradicate poverty now needs to be more spatially focused for the implementation to be more effective. Recognising the incidence of poverty through standard statistical data tables alone is no longer adequate in formulating planning and policy implementation. Through spatial autocorrelation analysis the pattern of distribution of poverty in space over a period of time can easily be visualised and hotspots of incidence of poverty identified. This paper attempts to show how this analysis can assist in focusing efforts to eradicate poverty in Malaysia.
\end{abstract}

Keyword: Poverty Distribution, Spatial Analysis, Malaysia 


\section{INTRODUCTION}

Malaysia was a low-income, predominantly agricultural and rural economy at the time of independence in 1957. There was widespread poverty involving about half of the country's households. More than a decade later in 1970, there was not much improvement; about 43 per cent of the households were still living in poverty (UNDP, 2007). Poverty eradication is primarily the responsibility of the national governments. Every government is confronted with this problem and various actions and solutions have been suggested and implemented but none have been able to eradicate it completely. However, that did not mean that the efforts to overcome poverty were fruitless as the fight against poverty is a continuous process.

In Malaysia's case, after more than four decades, the country has been transformed from a predominantly agricultural and rural economy, into a prosperous, urban, and industrialised economy with the issue of poverty reined in. Malaysia's efforts have been driven by the philosophy of "growth with equity" which reflected the government's commitment to eradicate poverty. This commitment was emphasised when the government committed itself with the United Nations Decade for the Eradication of Poverty programme 1997-2006 (Muda, 2005). When in September 2000 The Millennium Summit adopted the UN Millennium Declaration, committing nations to a new global partnership to reduce extreme poverty with a deadline of 2015, Malaysia's commitment was further reinforced.

In recognizing the multidimensional nature of poverty, Malaysia has pursued practical and integrated approaches to effectively eradicate poverty. The approaches were manifested in the policy focuses of its development plans (Table 1), namely, the New Economic Policy (NEP) 1970-1990, the National Development Policy (NDP) 1991-2000, the National Vision Policy 2001-2010, and the latest the New Economic Model (NEM) and the National Transformation Policy (NTP) which spans the period from 2011 until 2020.

Table 1: National Development Plans and Policy Focus

\begin{tabular}{|c|c|c|c|c|}
\hline Pre-NEP & $\begin{array}{c}\text { New Economic Policy (NEP) } \\
\text { OPP1 }\end{array}$ & $\begin{array}{l}\text { National Development } \\
\text { Policy (NDP) OPP2 }\end{array}$ & $\begin{array}{l}\text { National Vision Policy } \\
\text { (NVP) OPP3 }\end{array}$ & $\begin{array}{c}\text { National } \\
\text { Transformation Policy } \\
\text { (NTP) } \\
\text { New Economic Model }\end{array}$ \\
\hline $1960-70$ & $1971-90$ & $1991-2000$ & 2001-10 & $2011-20$ \\
\hline $\begin{array}{l}\text { First Malaysia Plan } \\
\qquad(1966-70)\end{array}$ & $\begin{array}{c}\text { Second Malaysia Plan } \\
\quad(1971-5) \\
\text { Third Malaysia Plan } \\
\quad(1976-80) \\
\text { Fourth Malaysia Plan } \\
\quad(1981-5) \\
\text { Fifth Malaysia Plan } \\
(1986-90)\end{array}$ & $\begin{array}{c}\text { Sixth Malaysia Plan } \\
\text { (1991-5) } \\
\text { Seventh Malaysia Plan } \\
(1996-2000)\end{array}$ & $\begin{array}{l}\text { Eighth Malaysia Plan } \\
\text { (2001-5) } \\
\text { Ninth Malaysia Plan } \\
(2006-10)\end{array}$ & $\begin{array}{c}\text { Tenth Malaysia Plan } \\
\text { (2011-15) }\end{array}$ \\
\hline
\end{tabular}

Source: Economic Planning Unit, Malaysia

Under the New Economic Policy (NEP), a 20-year time frame was established to reduce and eventually eradicating absolute poverty. At the same time it also aims to restructure society to equalize economic opportunity for all Malaysians by eliminating the identification of economic function with race. Under the NDP a special Development Programme for the Hardcore Poor (PPRT) was established, incorporating a package of 
economic, social, housing and the provision of basic amenities. The government also recognised the important role of non-governmental organisations (NGOs) as an integral part of the overall policy framework to eradicate poverty. Under the National Vision Policy (NVP) eradicating poverty irrespective of race, restructuring of society and balanced development remained as key strategies. The NEM and the NTP then focus in uplifting the bottom $40 \%$ of Malaysian households with the aim of ensuring that every Malaysian has an equal access and opportunity to be an active participant of the economic development. Vital to this is improving accessibility to good health care, housing, better education and the promotion of capacity building which are critical in raising the income and living standards of the poor in both, rural and urban households.

Through these policy focuses, coupled with sustained economic growth, the country reportedly has successfully reduced the rate of poverty. The general poverty rate has declined from $49.3 \%$ in 1970 to $1.7 \%$ in 2012 . The hardcore poverty rate has also declined from $6.9 \%$ in 1984 to $0.2 \%$ in 2012. As such, the Millennium Development Goal to halve the general poverty rate of $16.5 \%$ in 1990 by 2015 was achieved much earlier in the year 2000 (8.5\%) (Zainal Azman, 2013). Ultimately the government will be hoping to eventually eradicate absolute poverty in the future.

While the national poverty rate has shown remarkable reductions there are still substantial spatial and community variations. Thus poverty in Malaysia while it is not widespread is still visible. This paper attempts to map characteristics of poverty in Peninsular Malaysia.

\section{POVERTY IN MALAYSIA}

The discussion on poverty have suffered from the issue of inclusive and exclusiveness as it evolved over the years as have been argued by many authors such as Osutongun (1975); Voelkner (1981); Misturelli and Heffernan (2010); IFAD (1998); and the World Bank (2000). Different dimensions of poverty have been defined, among them the economic, human, political, socio-cultural and protective dimensions (OECD, 2003; 2010). The economic dimension identifies poverty as insufficient income to meet certain basic needs. The human dimension focuses directly on the question of an individual's access to basic needs, such as education, health and nutrition, without making specific reference to income. The political dimension refers to the deprivation of basic political and human rights as well as limited participation in public decision-making. The socio-cultural dimension indicates social exclusion and a lack of dignity within or between communities, while the protective dimension implies vulnerability to social, economic or security-related shocks (Steiner, 2007). Thus the essence of poverty definition has moved on from focusing on material aspects and confined to physical survival to it being multidimensional involving a larger spectrum of aspects. The issues of nutrition, housing, clothing, education, healthcare, powerlessness, isolation, vulnerability, market participation, "voicelessness", and rights have all been incorporated into the definitions of poverty (refer Table 2).

Poverty can be seen either in "absolute" or "relative" terms, with varying underlying principles and implications for policies and programs formulation. The concept of absolute poverty was defined as a condition in which the gross monthly income of a household was insufficient to purchase certain minimum necessities of life. These necessities were taken to include a minimum food basket to maintain household members 
in good nutritional health and other basic needs, viz., clothing and footwear, rent, fuel and power, transportation and communication, health-care, education and recreation. Thus it involves the setting of a 'poverty line' by estimating the minimum level at which an individual or household can subsist. Relative poverty categorises households as "poor" in comparison to those households in the neighbourhood or region whom they are part of. It is psychological in the sense that the poor are those who feel deprived of what is enjoyed by other people in society of which they consider themselves to be a part.

Table 2: Essence of poverty definitions

\begin{tabular}{|c|l|}
\hline Period & \multicolumn{1}{|c|}{ Essence of poverty definition } \\
\hline $\mathbf{1 9 7 0 s}$ & $\begin{array}{l}\text { Focus on material aspects - poverty viewed as the inability to fulfill the basic } \\
\text { requirements to attain a decent life and obtain adequate nutrition, housing and } \\
\text { clothing. }\end{array}$ \\
\hline Mid 1970s & $\begin{array}{l}\text { Expanded to include - a lack of education and healthcare, thus poverty was not } \\
\text { confined to physical survival, but became a social and institutional issue }\end{array}$ \\
\hline $\mathbf{1 9 8 0 s}$ & Expanded to include - notions of powerlessness, isolation and vulnerability \\
\hline $\mathbf{1 9 9 0 s}$ & $\begin{array}{l}\text { Modified to be recognized as multi-dimensional - inability to secure control of } \\
\text { resources such as land, water and income generating technologies leading to } \\
\text { exclusion from the market and therefore have no bargaining position }\end{array}$ \\
\hline $\mathbf{2 0 0 0 s}$ & $\begin{array}{l}\text { Further emphasis on the collective dimension of poverty - the importance of } \\
\text { 'giving a voice' to the poor, access to social services and capability to enjoy } \\
\text { human rights }\end{array}$ \\
\hline
\end{tabular}

Officially, poverty in Malaysia is measured only in absolute terms and the recommended practice by the World Bank was to use the national poverty lines where there exist (Zulkarnain and Isahaque, 2013). This practice was adopted by most countries since the 2005 Millennium Development Goal report (United Nations, 2011). In fact, Malaysia was amongst the first developing countries to define a 'national poverty line income' (PLI) which it officially formulated in 1977 (UNDP, 2007). Since the PLI was linked to the consumer price index (CPI), the PLI was periodically revised by the National Economic Action Council (NEAC) and the Economic Planning Unit (EPU) (Hendersen, et. al., 2005) in line with movements in the CPI. The resultant revisions now mean that the PLI takes into account not only the household's size and demographic composition; the household's location, and state and stratum (urban/rural), but also the CPI. In its effort to eradicate poverty Malaysia had also introduced the concept of "hard-core" poverty in 1984 to help identify and target poor households whose income is less than half of the PLI (DOS, 2010). Table 3 shows the Poverty Line Income by Region for 2012. 
Table 3: Poverty Line Income by Region 2012

\begin{tabular}{|r|c|c|c|c|}
\hline \multirow{2}{*}{ Region } & \multicolumn{3}{|c|}{ Poverty Line Income (PLI) 2012 (RM per month) } \\
\cline { 2 - 5 } & \multicolumn{2}{|c|}{ Poor } & \multicolumn{2}{c|}{ Hard Core Poor } \\
\cline { 2 - 5 } & Household & Per kapita & Household & Per kapita \\
\hline Peninsular Malaysia & 830 & 210 & 520 & 130 \\
\hline Urban & 840 & 220 & 510 & 130 \\
\hline Rural & 790 & 190 & 530 & 120 \\
\hline Sabah and Labuan & 1090 & 240 & 660 & 140 \\
\hline Urban & 1080 & 240 & 630 & 140 \\
\hline Rural & 1120 & 240 & 710 & 150 \\
\hline Sarawak & 920 & 230 & 600 & 140 \\
\hline Urban & 960 & 230 & 630 & 150 \\
\hline Rural & 870 & 220 & 570 & 140 \\
\hline
\end{tabular}

Source: Zainal Azman bin Abu Seman, 2013.

The incidence of absolute poverty and hard-core poverty in Malaysia has declined dramatically since 1970 and 1985 respectively. The decline can be observed for all states within the country. However, as Table 4 shows, the states that experiences incidences of poverty rates higher than the national average since the 1970s have remained the same. Sabah, Sarawak, Kelantan, Perlis, Kedah and Terengganu still recorded higher incidences of poverty than the national average.

Since the hard-core poverty group was introduced, the incidence of hard-core poverty has also declined. In 1985, six states were recorded to have rates higher than the national average. However, by 2012 only the states of Sabah, Sarawak, Kelantan, and Perlis have rates higher than the national average (Table 5). Of these only Sabah recorded a rate of more than one percent.

Discussions on incidence of poverty have also touch on ethnic groups. Although the incidences of poverty have declined tremendously since 1970 to 2012 for each ethnic group, poverty among the Bumiputera and Indian are still prevalent. Poverty among the Bumiputra is approximately seven times higher than the Chinese. While for the Indian they are six times higher. This shows the need for programmes to be targeted to these groups in order to eradicate poverty.

\section{DATA AND METHODS}

\section{Data}

The GIS data set for this study is utilized from secondary data which are poverty data by $e$-Kasih database from the Ministry of Women, Family and Community Development and 2010 census data from the Department of Statistic, Malaysia. The case study is in Peninsular Malaysia and the database is using mukim boundary. Mukim is a local administrative boundary akin to sub-district. Table 7 shows the population of each state in Peninsular Malaysia and the number of mukims per state from the year 2010 census. In 
total, there are 833 mukims with a total population of $21,406,803$ people in Peninsular Malaysia. The poverty data include data on education level, gender, employment status and age groups.

Table 4: Incidence of Poverty in Malaysia by state from 1970-2012 (\%)

\begin{tabular}{|c|c|c|c|c|c|c|c|c|c|c|c|}
\hline State & 1970 & 1976 & 1985 & 1990 & 1997 & 1999 & 2002 & 2004 & 2007 & 2009 & 2012 \\
\hline Johor & 45.7 & 29.0 & 12.2 & 9.8 & 1.6 & 2.5 & 1.8 & 2.0 & 1.5 & 1.3 & 0.9 \\
\hline Kedah & 63.2 & 61.6 & 36.6 & 29.9 & 11.5 & 13.5 & 10.7 & 7.0 & 3.1 & 5.3 & 1.7 \\
\hline Kelantan & 76.1 & 67.1 & 39.2 & 29.6 & 19.2 & 18.5 & 12.4 & 10.6 & 7.2 & 4.8 & 2.7 \\
\hline Melaka & 44.9 & 32.4 & 15.8 & 12.4 & 3.5 & 5.7 & 2.7 & 1.8 & 1.8 & 0.5 & 0.1 \\
\hline N. Sembilan & 44.8 & 33.0 & 13.0 & 9.1 & 4.7 & 2.5 & 2.2 & 1.4 & 1.3 & 0.7 & 0.5 \\
\hline Pahang & 43.2 & 38.9 & 15.7 & 10.0 & 4.4 & 5.5 & 3.8 & 4.0 & 1.7 & 2.1 & 1.3 \\
\hline Perak & 48.6 & 43.0 & 20.3 & 19.2 & 4.5 & 9.5 & 7.9 & 4.9 & 3.4 & 3.5 & 1.5 \\
\hline Perlis & 73.9 & 59.8 & 33.7 & 17.4 & 10.7 & 13.3 & 10.1 & 6.3 & 7.0 & 6.0 & 1.9 \\
\hline Pulau Pinang & 43.7 & 32.4 & 13.4 & 8.7 & 1.7 & 2.7 & 1.4 & 0.3 & 1.4 & 1.2 & 0.6 \\
\hline Selangor & 29.2 & 22.9 & 8.6 & 7.6 & 1.3 & 2.0 & 1.1 & 1.0 & 0.7 & 0.7 & 0.4 \\
\hline Terengganu & 68.9 & 60.3 & 28.9 & 31.3 & 17.3 & 14.9 & 10.7 & 15.4 & 6.5 & 4.0 & 1.7 \\
\hline Sabah & - & 58.3 & 33.1 & 34.3 & 16.5 & 20.1 & 16.0 & 24.2 & 16.4 & 19.7 & 7.8 \\
\hline Sarawak & - & 56.5 & 31.9 & 21.0 & 7.3 & 6.7 & 5.8 & 7.5 & 4.2 & 5.3 & 2.4 \\
\hline W.P.KL & - & 9.0 & 4.9 & 3.7 & 0.1 & 2.3 & 0.5 & 1.5 & 1.5 & 0.7 & 0.8 \\
\hline W.P Labuan & - & - & - & - & - & - & - & 2.7 & 4.2 & 3.8 & - \\
\hline Malaysia & 49.3 & - & 20.7 & 16.5 & 6.1 & 7.5 & 5.1 & 5.7 & 3.6 & 3.8 & 1.7 \\
\hline
\end{tabular}

Source: Economic Planning Unit, Malaysia, 2014.

Table 5: Hard Core Poverty in Malaysia by state from 1985-2012 (\%)

\begin{tabular}{|l|c|c|c|}
\hline \multicolumn{1}{c|}{ State } & $\mathbf{1 9 8 5}$ & $\mathbf{1 9 9 9}$ & $\mathbf{2 0 1 2}$ \\
\hline Johor & 3.1 & 0.3 & 0.1 \\
\hline Kedah & 13.5 & 3.0 & 0.1 \\
\hline Kelantan & 15.5 & 6.1 & 0.3 \\
\hline Melaka & 5.5 & 1.0 & - \\
\hline N. Sembilan & 3.7 & 0.4 & 0.1 \\
\hline Pahang & 5.4 & 1.2 & 0.2 \\
\hline Perak & 6.7 & 1.2 & 0.2 \\
\hline Perlis & 11.7 & 1.6 & 0.5 \\
\hline Pulau Pinang & 4.1 & 0.1 & 0.0 \\
\hline Selangor & 2.5 & 0.2 & 0.0 \\
\hline Terengganu & 11.6 & 5.1 & 0.2 \\
\hline Sabah & 9.7 & 7.1 & 1.6 \\
\hline Sarawak & 10.0 & 3.0 & 0.3 \\
\hline W.P.KL & - & - & 0.1 \\
\hline W.P Labuan & - & - & - \\
\hline Malaysia & 6.9 & 1.9 & 0.2 \\
\hline
\end{tabular}

Source: Economic Planning Unit, Malaysia, 2014. 
Table 6: Incidence of Poverty in Malaysia by Ethnicity from 1970-2012 (\%)

\begin{tabular}{|l|c|c|c|c|c|c|c|c|c|c|c|}
\hline \multicolumn{1}{|c|}{ Ethnic } & $\mathbf{1 9 7 0}$ & $\mathbf{1 9 7 6}$ & $\mathbf{1 9 8 5}$ & $\mathbf{1 9 9 0}$ & $\mathbf{1 9 9 7}$ & $\mathbf{1 9 9 9}$ & $\mathbf{2 0 0 2}$ & $\mathbf{2 0 0 4}$ & $\mathbf{2 0 0 7}$ & $\mathbf{2 0 0 9}$ & $\mathbf{2 0 1 2}$ \\
\hline Bumiputra & 64.8 & 46.4 & 28.7 & 23.0 & 9.0 & 12.3 & 9.0 & 8.3 & 5.1 & 5.3 & 2.2 \\
\hline Chinese & 26.0 & 17.4 & 7.8 & 5.4 & 1.1 & 1.2 & 1.0 & 0.6 & 0.6 & 0.6 & 0.3 \\
\hline Indian & 39.2 & 27.3 & 10.1 & 7.6 & 1.3 & 3.4 & 2.7 & 2.9 & 2.5 & 2.5 & 1.8 \\
\hline Others & 44.8 & 33.8 & 18.8 & 22.8 & 13.0 & 25.5 & 8.5 & 6.9 & 9.8 & 6.7 & 1.5 \\
\hline
\end{tabular}

Table 7: Population Data for Peninsular Malaysia

\begin{tabular}{|c|c|c|c|c|c|c|c|c|}
\hline$\underset{\overrightarrow{0}}{\stackrel{\mathscr{0}}{\overrightarrow{0}}}$ & 悥 & 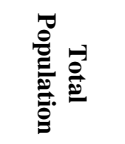 & & 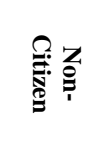 & $\frac{3}{2}$ & $\frac{2}{2}$ & 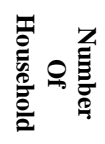 & 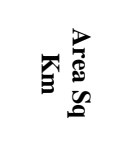 \\
\hline Johor & 93 & 3182290 & 2905079 & 253811 & 1667849 & 1491041 & 764271 & 19076.93 \\
\hline Kedah & 127 & 1974325 & 1878064 & 69561 & 985724 & 961901 & 460677 & 9467.52 \\
\hline Kelantan & 66 & 874070 & 263766 & 4204 & 132202 & 135768 & 179822 & 15026.01 \\
\hline Melaka & 82 & 785920 & 749115 & 33205 & 393872 & 388448 & 189670 & 1654.15 \\
\hline $\begin{array}{l}\text { Negeri } \\
\text { Sembilan }\end{array}$ & 63 & 1051181 & 992455 & 57526 & 544698 & 505283 & 251030 & 6653.14 \\
\hline Pahang & 71 & 1448777 & 1377853 & 70924 & 764256 & 684521 & 315310 & 35923.08 \\
\hline Perak & 82 & 2270318 & 2181081 & 68237 & 1135903 & 1113415 & 560763 & 20965.90 \\
\hline Perlis & 22 & 225630 & 220110 & 5520 & 111199 & 114431 & 53009 & 814.29 \\
\hline $\begin{array}{l}\text { Pulau } \\
\text { Pinang }\end{array}$ & 83 & 1650509 & 1554269 & 96240 & 827714 & 822795 & 419231 & 1043.55 \\
\hline Selangor & 54 & 5283804 & 4874244 & 406660 & 2734294 & 2546610 & 1324802 & 7957.81 \\
\hline $\begin{array}{l}\text { Tereng- } \\
\text { ganu }\end{array}$ & 81 & 1002868 & 975066 & 17102 & 504922 & 487246 & 209711 & 12948.17 \\
\hline $\begin{array}{l}\text { Federal } \\
\text { Territory }\end{array}$ & 9 & 1657111 & 1506943 & 150168 & 840564 & 816547 & 438698 & 285.91 \\
\hline Total & 833 & 21406803 & 19478045 & 1233158 & 10643197 & 10068006 & 5166994 & 131816.44 \\
\hline
\end{tabular}

\section{Standardized Poverty Rate (SPR)}

The data are concerned with the total number of households and poor households in every mukim. Comparing absolute number of poor households may not show the true difference between mukims as the mukims vary in terms of their total households. Normalization measure called Standardized Poverty Rate was applied in order to compare the mukims differences. The rate needed to be standardized and must be reliable for applying advanced analysis. The formula is shown in equation (1) and (2):

$$
\begin{aligned}
& S P R=\frac{P H H i}{E i} \\
& E i=\frac{\sum P H H i}{\sum P i} \times P i
\end{aligned}
$$

Where: SPR: Standardized Poverty Rate

PHH: Number of Poor Household in every mukim

Pi: Number of household living in every mukim

Ei: Predicted Poverty Rate for each mukim 


\section{GIS Application for Poverty Mapping}

The software used for GIS analysis was ArcGIS 10.0 with the ArcGIS Spatial Analyst and Spatial Statistic extension from the Environmental Research Institute (ESRI). ArcGIS software enabled to analyse the data based on location and lead to hot spot analysis (GetisOrd Gi*). A zone of Indifference was chosen as a method of analysis which depends on distance. The result of the analysis will show exactly which areas are highly poverty concentrated (Hot Spot) and which areas are having the least problems.

One of the main objectives of this research is to get the spatial autocorrelation of poverty rate of each mukim. These autocorrelation can be in different ways as they can be concentrated or clustered in a specific location or they can be a part of spatial outliers. Table 8 shows the classification of different types of poverty for mukims. For the analysis, Z score will be derived from Spatial Autocorrelations (Moran's I) tools in ArcGIS. As results, Spatial Autocorrelation will give a Z score for each mukim with different distances which will be used as distance band.

Table 8: Moran's I Z-Score and SPR classifications

\begin{tabular}{|l|l|c|}
\hline Category & Standardized Poverty Rate & Local Moran's Z Score \\
\hline High poverty (concentrated) & $>$ 2SDs above mean & $\geq 2.0$ \\
Poverty (concentrated) & Between 1 and 2SDs above mean & $\geq 2.0$ \\
High poverty (spatial outlier) & $>$ 2SDs above mean & $\leq-2.0$ \\
Poverty (spatial outlier) & Between 1 and 2SDs above mean & $\leq-2.0$ \\
Very low poverty (concentrated) & $>$ 2 SDs below mean & $\geq 2.0$ \\
Low poverty (concentrated) & Between 2 and 1 SDs below mean & $\geq 2.0$ \\
Very low poverty (spatial outlier) & $>2$ SDs below mean & $\leq-2.0$ \\
Low poverty (spatial outlier) & Between 2 and 1 SDs below mean & $\leq-2.0$ \\
Other & Within 1 SD of mean & -2.0 to 2.0 \\
\hline
\end{tabular}

\section{RESULTS ON SPATIAL DISTRIBUTION OF POOR POPULATION IN PENINSULAR MALAYSIA}

This section presents the spatial dimension of poverty. Different maps are presented in different categories. The first few maps discuss on the distribution of poor households in Peninsular Malaysia and the locations of extreme poverty before showing the hot and cold spots of poverty. This is follwed by a collection of maps depicting the distribution of poor household heads (PHH) according to various characteristics including gender, age group, employment and educational level.

\section{Poverty Across the Peninsular}

Poverty is concentrated in several mukims in Peninsular Malaysia (Figure 1). Areas with highest poverty concentration are northeast Kelantan and Hulu Terengganu. These areas have several mukims with more than 15 poor HH per 1000 population. Second serious areas are northeast Kedah and northwest Selangor and also several mukims in central Perak. Mukims southward from Klang valley have low incidence of poverty except for very few mukims in Negeri Sembilan and Melaka and a few in Johor. On average their 
rates are less than 3 poor $\mathrm{HH}$ per 1000 population which is far lower than the national average of $220 \mathrm{HH}$ per 1000 population.

\section{PovertyHot Spots}

The three prominent poverty hot spots are: 1) Northern Kelantan together with northern Terengganu bordering Kelantan; 2) Middle Terengganu plus Hulu Terengganu; 3)Northeastern Kedah. Cold spots are around the urban capitals of Kedah, Pulau Pinang, Selangor/Wilayah Persekutuan and Melaka. See Figure 2 below.

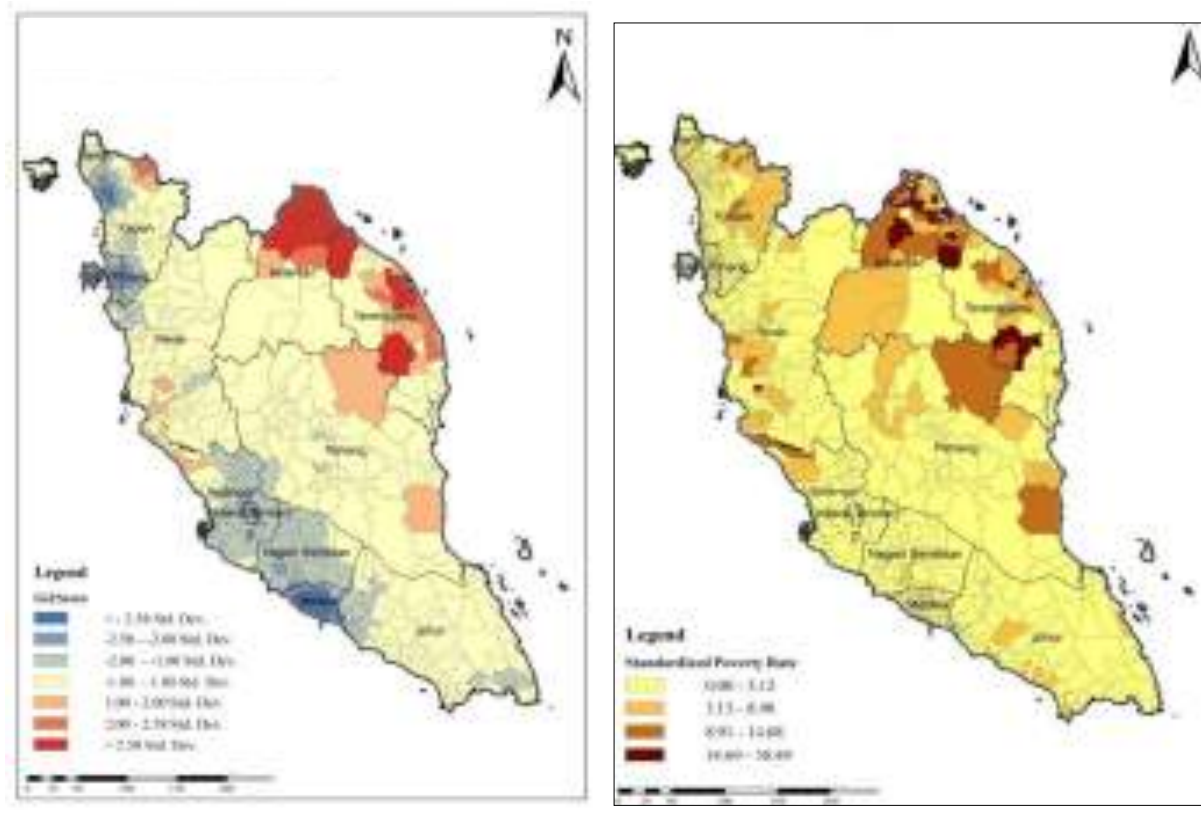

Figure 1: Standardized poverty rates by mukim in Peninsular Malaysia Figure 2: Hot and cold mukims of poverty in Peninsular Malaysia

\section{Extreme Poverty Areas}

High poverty ( $>2 \mathrm{SD}$ ) are concentrated in northern Kelantan and Hulu Terengganu. These mukim are surrounded by poor mukims with $(1<\mathrm{SD}<2)$. Pulau Aman And Pulau Gudung in Pulau Pinang are very poor mukims that are a spatial outliers. 


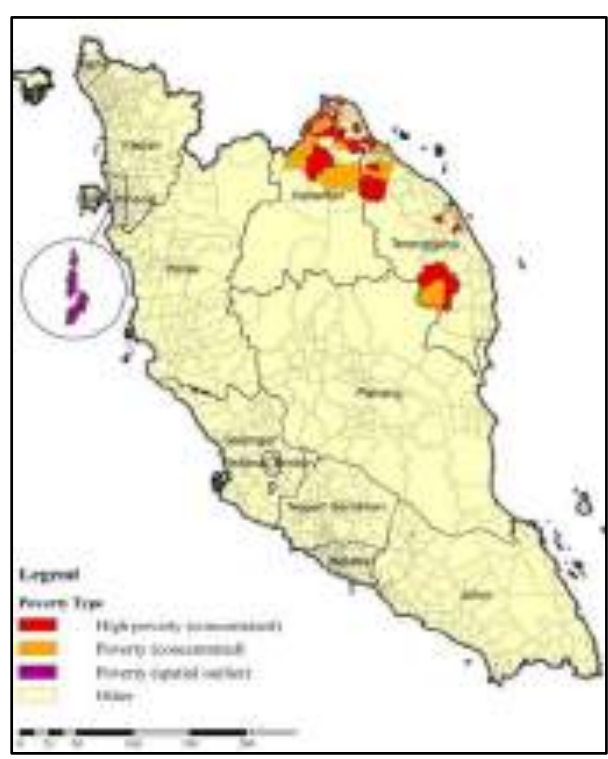

Figure 3: Areas of extreme poverty in Peninsular Malaysia

\section{Gender of Head of Poor Households}

Poor households headed by males are dominant in eastern states of Kelantan \& Terengganu and Northern states of Perak, Kedah and Penang. Interestingly, poor households headed by females are more dominant in the south especially in and around the state of Negeri Sembilan where matrilineal adat pepatih custom is widely practiced by the Minangkabau household. Blank (white) mukims mean no data was available for the mukim during research. Figure 4 below highlights the distribution of the poor households based on gender of household heads. 

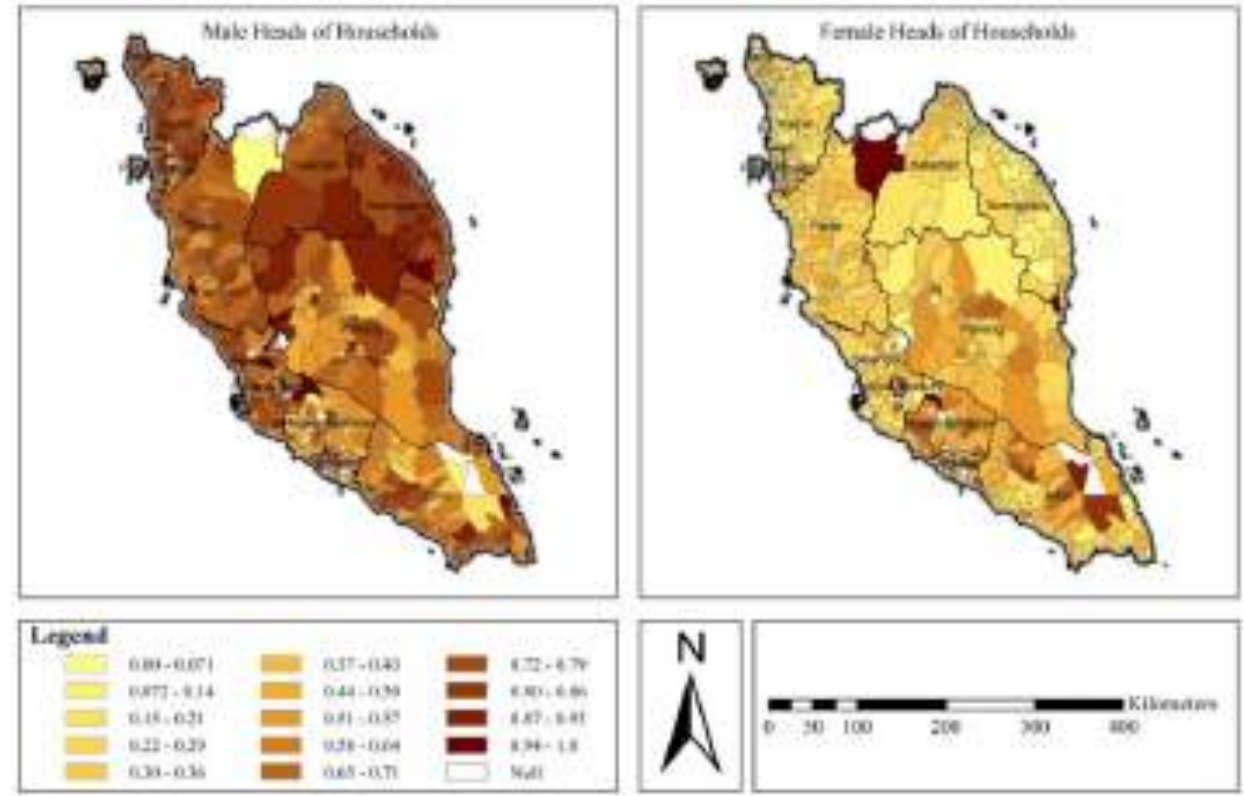

Figure 4: Distribution of poor households according to gender of household heads

\section{Age Range of Head of Poor Households}

Majority of te heads of the poor households are aged 40-59 years old. This conforms to many studies in developing countries. This is the period when most people are active in life; most people are married and working between age 40 - 59 with children attending school and not contributing into the family coffers for the upkeep of the family. Fewer households had their head's aged 18-39. This is because at this age most people are still schooling or learning a vocation and therefore cannot assume headship of the family. Most people at age 18-39 are still dependent on the active working force within age 4059. There were some head of household aged 60yrs and above. Most of the heads 60yrs and above had kids that were grown up and were therefore not leaving within the household. Most of them were supporting their aged parents who are $60 \mathrm{yrs}$ and above. See Figure 5 below further elaboration.

\section{Employment of Heads of Poor Households}

Most heads of poor households are either self-employed, wage earners or unemployed. Interestingly however most heads who are self employed or wage earners are in the very north and northeast states of Kedah, Kelantan and Terengganu. The heads of poor households in these rural areas are simply not making enough money on their own (selfemployed) or not getting paid enough wages (wage earners) for their labour. While those heads of poor households who hold no jobs are mostly in the urban areas of Klang Valley and Malacca. Figure 6 depicts these phenomena. 


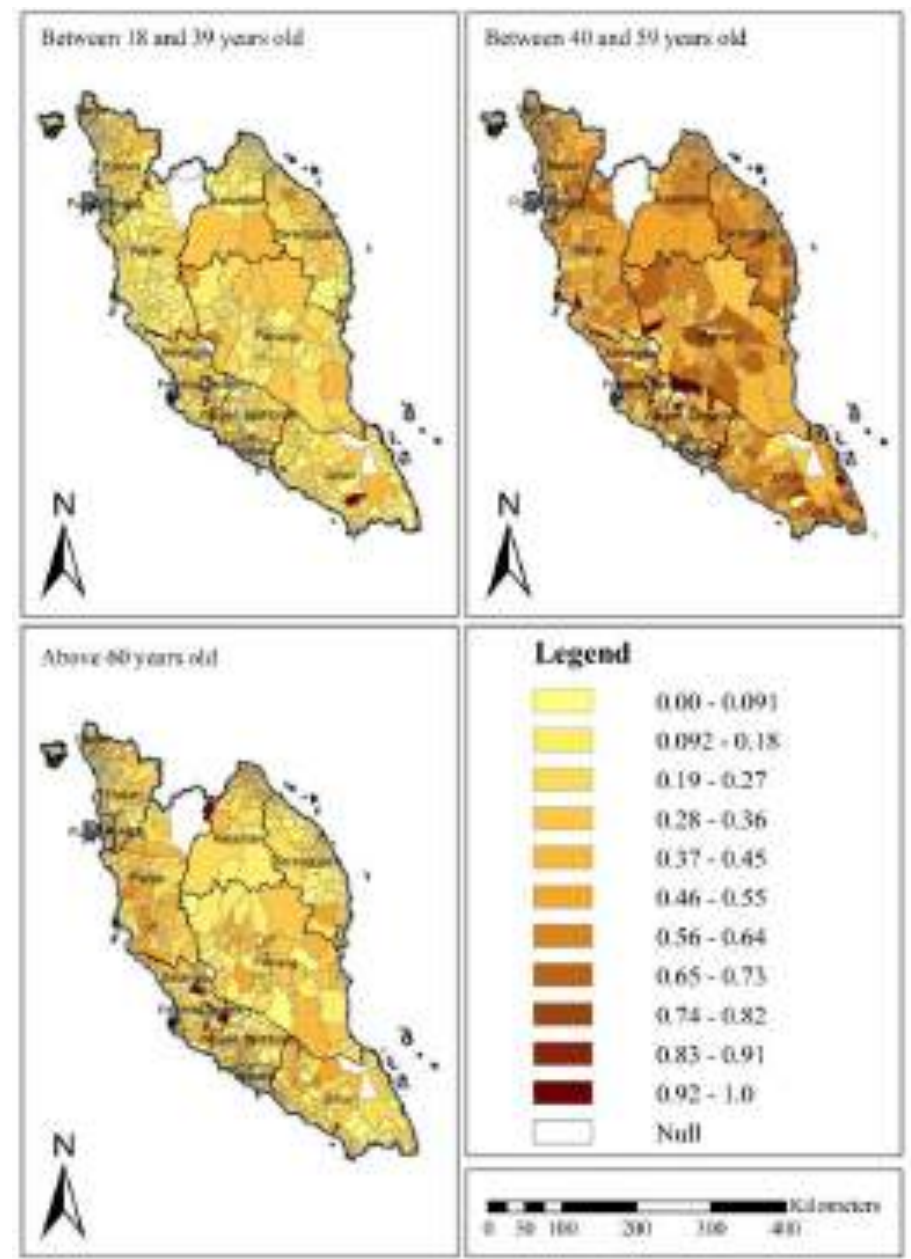

Figure 5: Distribution of poor households according to age of household heads

\section{Education of Heads of Poor Households}

Education indeed plays a major role in poverty levels. Majority of the poor household heads had no certificate to show for their education (> 50\%) as shown in Figure 7. Poorly educated heads of households are more likely to be poor. Most of the poor head of household are with no certificate at all or at the most finished only primary school (UPSR certificate). Those with at least a diploma are very unlikely to be poor and poor heads of households with at least SPM-level qualification are more concentrated in the urban area. 

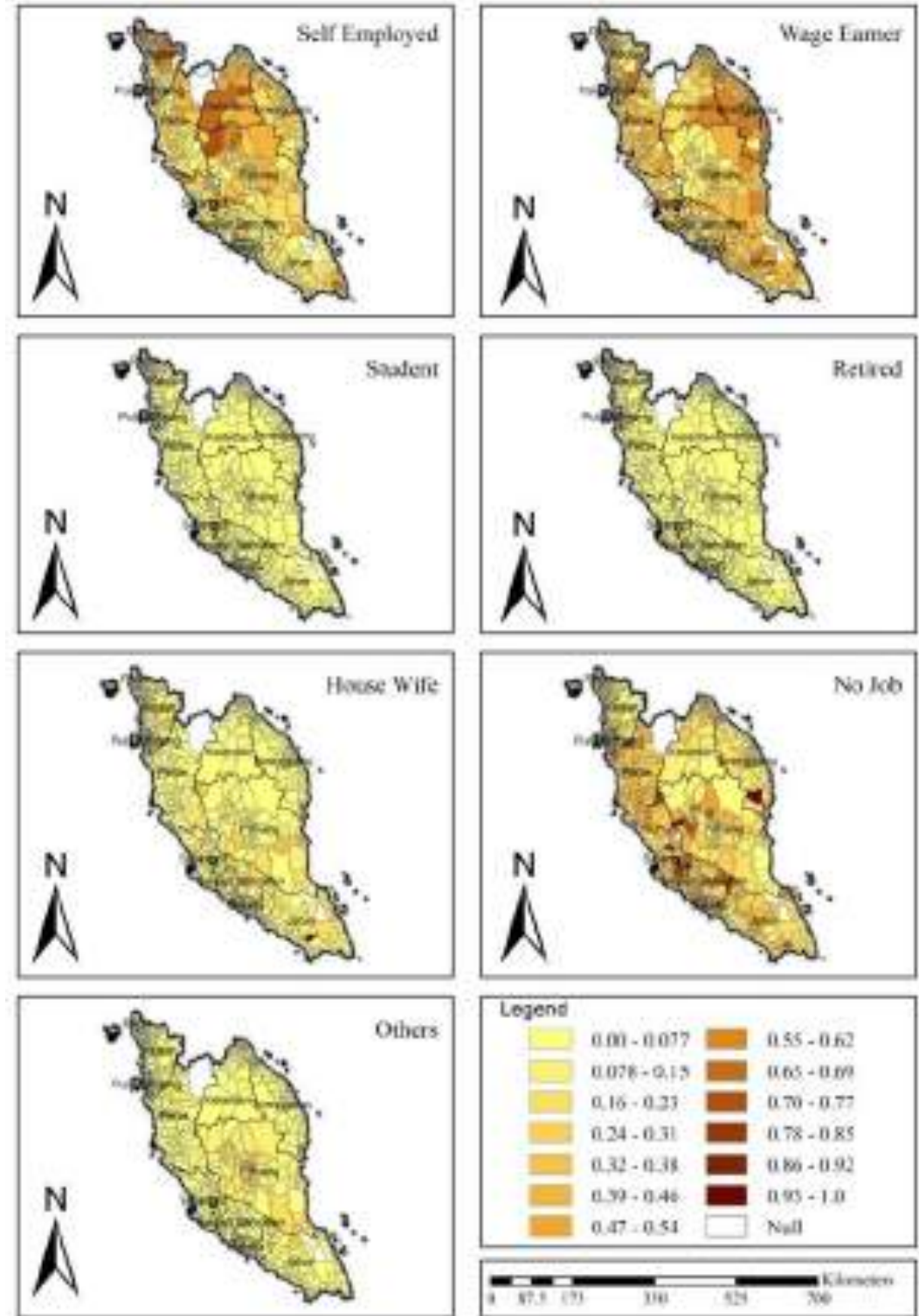

Figure 6: Distribution of poor households according to employment of household heads 


\section{CONCLUSION}

The main development goal in Malaysia's development agenda since independent has been poverty eradication as well as bridging the inequality gap among the major ethnic groups and states. The principle of "growth with equity" has been the central theme in all Malaysians' development policies and efforts since independence. Malaysia has consistently formulated a number of policies and plans to guide the management of national development and poverty reduction since independence.

Areas with highest poverty concentration are northeast Kelantan and Hulu Terengganu. These areas have several mukims with more than 15 poor households per 1000 population. Second serious areas are northeast Kedah and northwest Selangor and also several mukims in central Perak. The three prominent poverty hot spots are: 1) Northern Kelantan together with northern Terengganu bordering Kelantan; 2) Middle Terengganu plus Hulu Terengganu; 3) Northeastern Kedah. Extreme areas with high poverty concentration of more than two standard deviations are concentrated in northern Kelantan and Hulu Terengganu. These mukims are surrounded by poor mukims $(1<\mathrm{SD}<2)$ except for Pulau Aman and Pulau Gudung in Pulau Pinang which are outlier very poor mukims surrounded by relatively rich mukims.
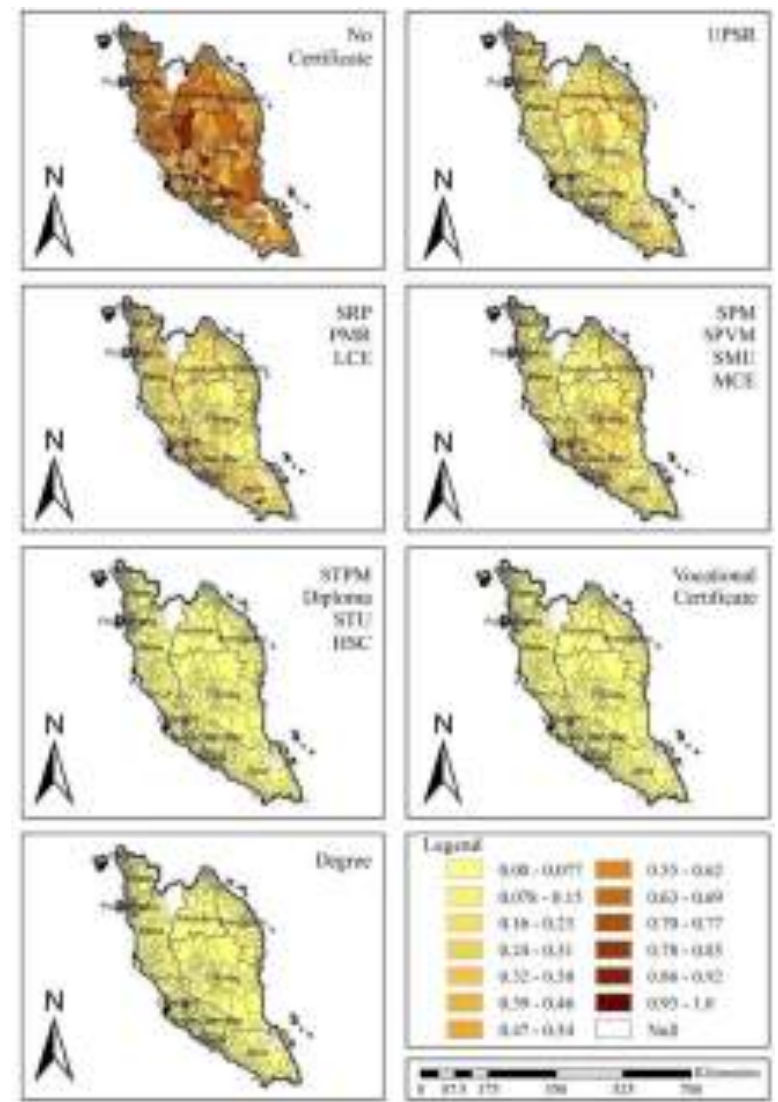

Figure 7: Distribution of poor households according to education of household heads 
The analysis also revealed that poor househols headed by males are dominant in eastern states of Kelantan and Terengganu and Northern states of Perak, Kedah and Penang. Poor households headed by females are more dominant in the south especially in and around the state of Negeri Sembilan where the matrilineal adat pepatih custom is widely practiced by the Minangkabau household. Majority of poor household heads are aged 40-59 years old. Most heads of poor households are either self-employed, wage earners or unemployed, especially in northeast Kedah, Kelantan \& Terengganu.

The study has shown and highlighted the pattern of distribution of poverty in space which is helpful in planning and informing policy formulation to eradicate poverty in peninsular Malaysia. Inequality between states, regions and mukims still remain wide and persistent. In order to achieve the objective of ensuring that the benefits of economic growth are shared equitably among all Malaysians, it is imperative to intensify the poverty reduction efforts in the regions and mukims showing extreme poverty in order to sustain economic growth as well as for the maintenance of social stability and national unity. Government should concentrate its poverty reduction efforts in areas with highest poverty concentration such as northeast Kelantan and Hulu Terengganu, Northeast Kedah and Northwest Selangor and central Perak. In order to achieve the objective of ensuring that the benefits of economic growth are shared equitably among all Malaysians it is imperative to intensify the poverty reduction efforts in the regions showing extreme poverty in order to sustain economic growth as well as for the maintenance of social stability and national unity.

\section{ACKNOWLEDGMENTS}

The authors acknowledge the funding support for this research provided by The Centre for Innovative Planning and Development (CiPD), Universiti Teknologi Malaysia under its special research grant scheme.

\section{REFERENCES}

Department of Statistics Malaysia. (2010). Monthly Statistical Bulletin. Retrieved from http://www .statistics. gov.my

Henderson, J. David Hulme, Richard Phillips and Noorul Ainur M Nur. (2005). Economic Governance and Poverty Reduction in Malaysia. Globalisation and Poverty. May, 2005.

IFAD. (1998). Annual Report 1997: International Fund For Agricultural Development.

Kamarudin Muhamed and Shahriman Haron. (2011). Poverty Mapping: An Effective Approach in Determining The Poor Area-Case Study Of Johor, Journal of The Department of Statistics, Malaysia, Volume 1, 2011,Department Of Statistics, Malaysia, 2011

Misturelli, F., \& Heffernan, C. (2010). The Concept Of Poverty: A Synchronic Perspective. Progress In Development Studies, 10(1), 35-58.

Muda, M.A, (2005). Implementation of The First United Nations Decade for The Eradication of Poverty (1997-2006), At The Second Committee of The 60th Session The United Nations General Assembly New York, 15 November 2005.

OECD (2003, 2010). Rural Poverty Report. The Challenge of Ending Rural Poverty. New York: Oxford University Press Inc. 
Osutongun, A. (1975). Poverty As An Issue In Rural Development Policy: A Case Study From The Western States Of Nigeria. . In Poverty In Nigeria, The Nigerian Economics Society, Department of Economics, University of Ibadan, 191-199.

Steiner, S. (2007). Decentralisation and Poverty: Conceptual Framework and Application To Uganda. Public Administration and Development, 27, 175-185.

UNDP, (2007). Malaysia Measuring and Monitoring Poverty and Inequality, United Nations Development Programme (UNDP), Malaysia.

United Nations. (2011). Malaysia: The Millennium Development Goals At 2010. United Nations Country Team, Kuala Lumpur: Malaysia.

Voelkner, H. (1981). Monitoring Poverty By Basic Needs Items In Clayton, E. and Pétry, F. Editors, . Monitoring Systems For Agricultural And Rural Development Projects, 12.

Worldbank. (2000). World Development Report 2000/2001. Attacking Poverty. Oxford University Press For The World Bank.

Zainal Azman Bin Abu Seman. (2013). Poverty and Inequality in the Context of Malaysia Development Strategy, Poverty and Inequality in Asia workshop, Bali, Indonesia on 7-9 May 2013.

Zulkarnain A. Hatta1 \& Isahaque Ali. (2013). Poverty Reduction Policies In Malaysia: Trends, Strategies And Challenges, Asian Culture And History; Vol. 5, No. 2; 2013. Published By Canadian Center of Science And Education 